Biol. Stud. 2016: 10(2); 123-132 • DOI: https://doi.org/10.30970/sbi.1002.478

www.http://publications.Inu.edu.ua/journals/index.php/biology

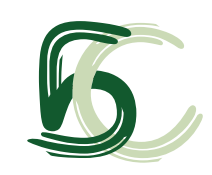

UDC 574.472.42

\title{
BASIC APPROACHES TO DETERMINING STABILITY OF POPULATIONS OF RARE PLANT SPECIES
}

H. O. Klymenko, I. M. Kovalenko

Sumy National Agrarian University, 160, Gerasym Kondratjev St., Sumy 40021, Ukraine e-mail: hgrip@rambler.ru

The results of approbation of three methods of an estimation of stability and probable development trends of populations on the example of rare plant species of $\mathrm{Na}$ tional natural park „Desnyansko-Starogutsky” are presented. The study objects were three rare plant species of NNPDS listed in the third edition of the Red Data Book of Ukraine: Epipactis helleborine (L.) Crantz (the population occurs in the phytocoenosis Querceto-Pinetum coryloso (avellanae)-caricosum (ericetorum), Listera ovata (L.) R. Br. (in the phytocoenosis Betuleto-Pinetum coryloso (avellanae)-stellariosum (holosteae) and Platanthera chlorantha (Cust.) Rchb. (sporadically spread throughout the woodlands in National Nature Park "Desniansko-Starogutsky", in Querceto-Pinetum coryloso (avellanae)-caricosum (ericetorum). It is established that MVP and the analysis of populations structure methods do not give a trustworthy information about the real development trends in local populations, particularly if in disposal of researcher data only for one or for 2-3 years of observations are available. PVA is a highly effective method that enables to assess stability of plant populations on a complex of individuals features in the population and population characteristics as a biological integrity. Thus, three methods revealed the likelyhood of degradation of $E$. helleborine and $L$. ovata local populations and relatively higher stability of local population of $P$. chlorantha. The organization of long-term monitoring of local populations of rare plant species is recommended on all protected areas.

Keywords: MVP method, PVA method, rare plants, populations, stability, dynamics.

\section{INTRODUCTION}

In recent decades floral diversity has been declined. Comparing the data of the 2 edition of the Red Data Book of Ukraine published in 1996 and the 3 edition published in 2009 , the authors state that "in general, the situation with the conservation of rare plant species... has worsened during this period" [13]. More and more species are getting endangered. Simultaneously with the publication of the Red Data Books, regional lists of rare plant species, enlargement of protected areas and development of ecological network of Ukraine, an important component of the scientific basis for the flora protection is a detailed study of local populations of rare plant species with the assessment of their

ISSN 1996-4536 (print) • ISSN 2311-0783 (on-line) • Біологічні Студії / Studia Biologica • 2016 • Том 10/№2 • С. 123-132 
stability and eventual dynamics of their development. S. L. Mosiakin and Yu. Ya. Tykhonenko [8] note that this direction in terms of systematic monitoring of rare plant species is one of the most actual for modern botany. The same view is shared by many leading phytosozologists, such as T. L. Andrienko [1], Ya. P. Didukh [3], A. V. Lucash, and T. L. Andriienko [7] and others.

From this perspective, the task was to analyze methods of assessment of stability of the populations of rare plant species, and on the basis of its results to assess the status and eventual population dynamics of three rare plant species of the Orchidaceae family, listed in the Red Data Book of Ukraine and protected in National Nature Park "Desniansko-Starogutsky" (NNPDS).

\section{MATERIAL AND RESEARCH METHODOLOGY}

The field studies were conducted in 2009-2011. The study objects were three rare plant species of NNPDS listed in the 3 edition of the Red Data Book of Ukraine published in 2009:

Epipactis helleborine (L.) Crantz; the population grows in the phytocoenosis Querceto-Pinetum coryloso (avellanae)-caricosum (ericetorae).

Listera ovata (L.) R. Br.; the local population - in the phytocoenosis BetuletoPinetum coryloso (avellanae)-stellariosum (holosteae).

Platanthera chlorantha (Cust.) Rchb.; it is sporadically spread throughout woodlands in NNPDS. The studied population is a component of Querceto-Pinetum coryloso (avellanae)-caricosum (ericetorae).

The generally accepted methods in geobotany and population ecology of plants were used to obtain the field data. For accurate counting all the individuals were marked. Ontogenetic and vitality structure of the populations was determined in accordance with the techniques of T. A. Rabotnov [10] and Yu. A. Zlobin [4, 6] using the ANONS and VITAL computer programs. Forecasts of the stability and possible dynamics of the studied plants populations were made using three independent methods with the aim of their testing and assessing their effectiveness: a) the MVP methodology - minimum viable population, b) the actual population structure and b) the PVA methodology (population viability analysis). The POPULUS [15] and VORTEX [25] non-commercial computer programs were used to make the calculations.

\section{RESULTS AND THEIR DISCUSSION}

The MVP Methodology. This methodology is based on the ideas of island biogeography [29] and involves short- or long-term census of the population and finding the trend in this number [28]. The application of the simplified genetic models has led to the conclusion that there is a general threshold for survival of populations of living organisms, and it is equal to $\mathbf{5 0 - 5 0 0 ~ i n d i v i d u a l s ~ t h a t ~ i s ~ r e g a r d e d ~ a s ~ t h e ~ " e f f e c t i v e ~ p o p u l a t i o n ~ s i z e " . ~}$

The results of counting the number of individuals in the populations of rare plant species in NNPDS based on MVP for three years are shown in Fig. 1. It is seen that for three years there has been a general reduction in the number of individuals in all local populations. The sharpest decline was observed in L. ovata. The assessment of prospective number trend with the use of a simple linear regression [20] has shown that there is a probability of complete extinction of the $L$. ovata and $E$. helleborine local populations by 2014 , whereas the $P$. chlorantha population can exist until 2021 under the trend established in 2009-2011.

ISSN 1996-4536 (print) • ISSN 2311-0783 (on-line) • Біологічні Студії / Studia Biologica • 2016 • Том 10/№2 • С. 123-132 


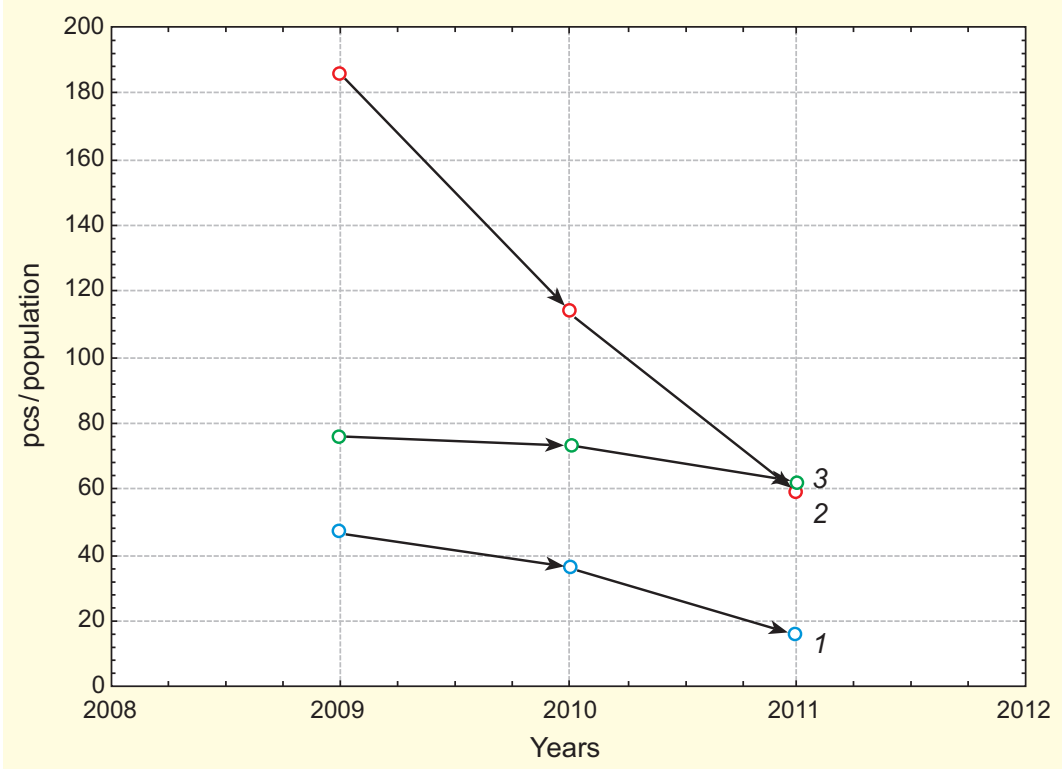

Fig. 1. Dynamics of the number of individuals in the populations of rare plant species in 2009-2011: 1Epipactis helleborine; 2 - Listera ovata; 3 - Platanthera chlorantha

Рис. 1. Динаміка чисельності особин у популяціях рідкісних видів рослин у 2009-2011 рр.: 1 - Epipactis helleborine; 2 - Listera ovata; 3 - Platanthera chlorantha

When interpreting the obtained results, it should be taken into account that the assessment of trends in the number counted on the basis of the MVP method, as indicated by a number of researchers, has a low validity, and the shorter the series of observation is, the lower this reliability is. This is due to the fact that many populations of rare plant species are characterized by rather sharp annual fluctuations in their number. On the basis of long-term monitoring of populations of one rare species, Elzinga et al. [21] found that for the first 8 years the number of individuals has decreased almost twice, and has increased by 2.5 times in the next 11 years. The work of $\mathrm{H}$. Jacquemyn et al. [22] contains the unique data based on the observations over the Spiranthes spiralis (L.) Chevall. (Orchidaceae) population during 25 years. It has turned out that the number of individuals in this population ranges by years from 80 to a few pieces, and the proportion of flowering plants varies from 0 to $100 \%$. It is obvious that on the basis of a random 3-5-year period of time as a part of this 25-year observation over population, it is possible to make inappropriate conclusions about its viability.

Thus, the method of accounting dynamics of the number of individuals in populations (especially over short time periods of about 3-5 years) cannot be considered effective to predict the population stability. G. Meffe et al. [24, p. 151] summarized this method of assessment of the population stability: "It would be naive to think that someone with a simple magic number could control the population, and when this number were reached, the population would be safe". It is also naive to conclude on the population's future based on the trends in the number of individuals for a small number of years.

But the data on negative trends of individuals in the populations of the studied plants itself, even for a short three-year period of time, should set the researcher on the 
alert and make him to organize long-term monitoring of the similar populations and use more powerful modern techniques to establish their stability.

Method of analysis of the population structure. To assess the status and stability of the populations of rare plant species many researchers make the analysis of their ontogenetic structure with evaluation of the population type (invasive, normal or regressive) and analysis of vitality structure with the division of populations by type of this structure into prosperous, equilibrium and depressive. These works quite often contain evaluation of the stability and trend of the population development only on the basis of the internal population structure once established.

Terminology for the names of population types, which is used to define the vitality and ontogenetic structure of populations, has turned out to be somewhat ambiguous. The names of population types that are determined on the basis of one year, seldom 2-3 years, with the record of ratio of individuals of different ontogenetic or different vitality condition in the population: "invasive", "regressive" (T. A. Rabotnov), "prosperous", "depressive" (Yu. Ya. Zlobin) seem to suggest that some populations are implemented in the coenosis, while others are in the condition of reduced viability and, therefore, fall out from it. A lot of researchers have started to fall into the trap of such terminology and to conclude on the stability or possible degradation of the local populations of rare plant species on the basis of the ontogenetic spectrum once established [2, 9, 12, and others]

In fact, these terms, as well as the information on the basis of which the category of population is determined, are not originally associated with the dynamic status of these populations. Such categories as "invasive", "regressive" and others only reveal the form in which populations of plant community exist, and nothing more. Depending on the life form of plants, length of individual occurrence in a particular ontogenetical condition, populations can be invasive, regressive or depressive for many decades [11]. In order to make a reliable diagnosis of stability of the populations of rare plant species, it is necessary to analyze the direction, in which ontogenetic or vitality structure of populations varies for quite a long period of time. The period required for monitoring is shorter for annual grasses, and longer for perennial grasses, and shall not be less than two decades for shrubs and trees.

To test the method of analysis of the population structure we have recorded ontogenetic and vitality structure of the populations of the studied species of rare plants in NNPDS for three years. The results of these surveys are presented in Table.

\section{Ontogenetic and vitality structure of populations of rare plant species}

\section{Онтогенетична і віталітетна структура популяцій рідкісних видів рослин}

\begin{tabular}{|c|c|c|c|c|c|c|}
\hline \multirow[t]{2}{*}{ Species } & \multicolumn{3}{|c|}{$\begin{array}{l}\text { Ontogenetic structure and } \\
\text { generative individuals, } \%\end{array}$} & \multicolumn{3}{|c|}{$\begin{array}{l}\text { Vitality structure and } \\
\text { vitality index } Q\end{array}$} \\
\hline & 2009 & 2010 & 2011 & 2009 & 2010 & 2011 \\
\hline Epipactis helleborine & $1-38.3$ & I - 30.6 & I -14.5 & $E-0.25$ & $E-0.25$ & $\mathbf{P}-0.38$ \\
\hline Listera ovata & I - 37.1 & I - 21.1 & I - 37.3 & $E-0.27$ & $\mathbf{P}-0.35$ & $E-0.29$ \\
\hline Platanthera chlorantha & I - 14.5 & I -11.0 & $\mathrm{I}-4.8$ & $\mathbf{P}-0.39$ & $\mathbf{E}-0.27$ & $\mathbf{D}-0.10$ \\
\hline
\end{tabular}

Comments: I - invasive population; P - prosperous population; E - equilibrium population; D - depressive population

Примітки: I - інвазійна популяція; P - процвітаюча популяція; E - рівноважна популяція; D - депресивна популяція

ISSN 1996-4536 (print) • ISSN 2311-0783 (on-line) • Біологічні Студії / Studia Biologica • 2016 • Том 10/№2 • С. 123-132 
Using a formal approach and considering the structure of populations only, we can conclude that as the studied populations belong to the category of invasive, we can observe a rapid introduction of the studied species into the forest phytocoenoses of NNPDS. This conclusion may seem quite significant, because for three years the vitality analysis of the population has given positive results: the populations belong to the category of equilibrium or prosperous with the index of vitality amounted to $0.25-0.39$, and only the population of $P$. chlorantha was in a depressed vitality condition $(Q=0.10)$ in 2011 .

Evaluating the obtained actual data, it is necessary to take into consideration that propagation by seed is important for sustainable existence and maintaining the studied local populations of three species of the Orchidaceae family. But the number of generative plants in the populations is critically small. In 2011, in absolute terms the number of $L$. ovata was 22 pcs., and the number of E. helleborine and P. chlorantha amounted to 3 pcs. Therefore, the presence of pollinating insects, specific for members of the Orchidaceae family, provided the small number of flowering plants, can be a critical factor for conservation of the studied populations. It must be acknowledged that the risk of extinction of these local populations is quite high, regarding the three-year trend in reducing the number of individuals in populations.

The PVA Methodology. PVA can be defined as the methodology for assessment of the probability of survival of a population during a certain period of time, which is based on a comprehensive analysis of the viability of individuals in the population and viability of populations as biological integrity. Over the past decade and a half, a lot of survey and methodical works have been devoted to PVA [14, 16-19, 30].

Currently, there are five main varieties of PVA:

1. Simple PVA, which is based on determining the number of individuals in the population and defining the possible trend of this magnitude, given the specific growth rate of the population, and often amended in response to stochastic factors.

2. Structural PVA, which is based on a metric model of the demographic characteristics of the population (the individuals are divided into groups (classes) by ontogenetic condition or size), including the specific growth rate of the population, the fecundity of individuals, the risk of dying-off of various groups of individuals etc.

3. Metapopulation PVA, which is applied to a set of populations or a fragmented population. It takes into account the rate of fragmentation and the risks of extinction of individual subpopulations.

4. "Spatially accurate" PVA, which includes the mandatory mapping of the population fields that allows us to consider the size of subpopulations and the real distances between them.

5. Multispecies PVA, in which all species, included in the aggregation, are evaluated. The implementation of this form of PVA in relation to all dominants or characteristic species of a certain phytocoenosis gives the opportunity to assess the stability and trend of transformation of plant aggregation as a whole [26].

The basic source model in calculation of the dynamics of populations according to the PVA method is the following equation:

$$
N_{t+1}=\lambda N_{t},
$$

where $N_{t}$ is the number of individuals in the population in the year of $t, \lambda$ is the specific growth rate of the population.

The basic idea of the PVA method is to use as much information about the condition of the populations as possible for quite a long period of time in order to assess their

ISSN 1996-4536 (print) • ISSN 2311-0783 (on-line) • Біологічні Студії / Studia Biologica • 2016 • Том 10/№2 • C. 123-132 
stability. M. A. McCarthy et al. [23] believe that to predict the condition of the populations for the next 100 years, it is necessary to obtain output at least for 10 years of continuous population monitoring.

The following data is, at least, required to implement the PVA methods: a) the number of individuals in the population, b) the birth rate, c) the mortality rate, d) the specific plant fecundity, e) the demographic structure of populations with the division of individuals into classes of ontogenetic or vitality condition (no less than 3-5 classes, but division into 15 classes is used in some cases). Selection of the essential indicators is individual for different plant species.

PVA does not provide versatile techniques to assess stability of populations due to the individuality of biology and ecology of species and specificity of ecological and coenotic conditions, under which the studied population existed. It is necessary to re-solve the task for each plant species and each situation [5].

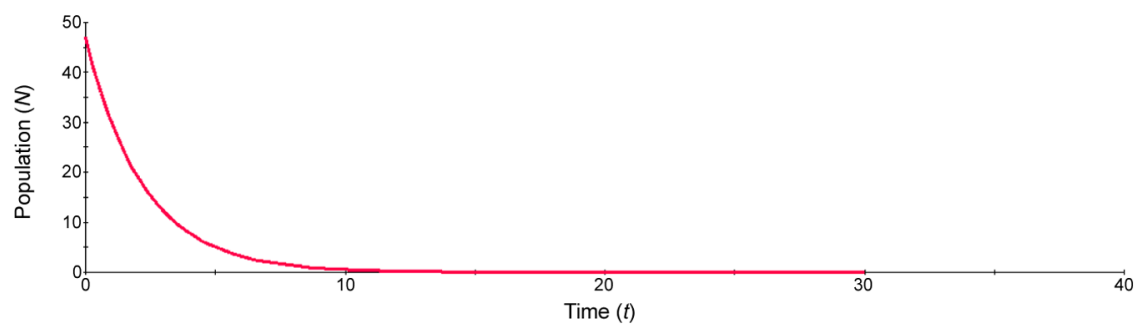

Epipactis helleborine

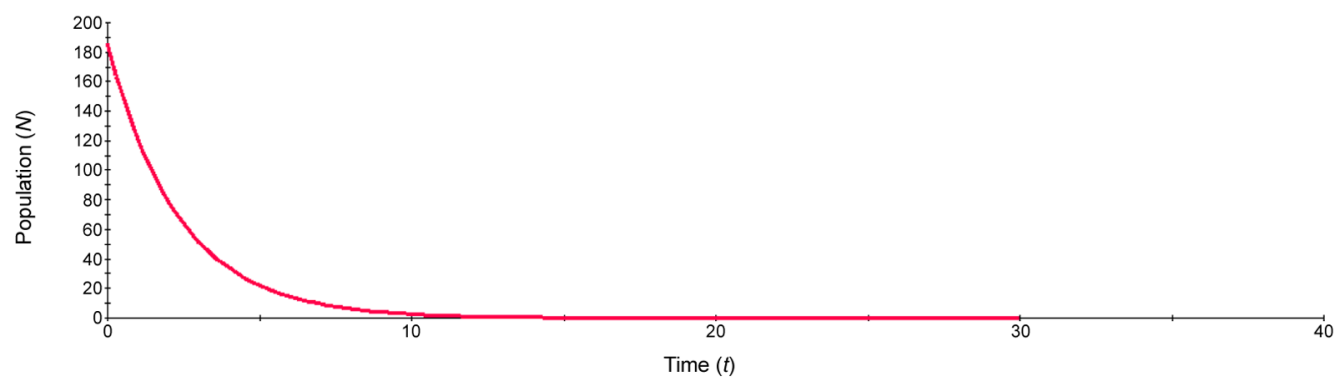

Listera ovata

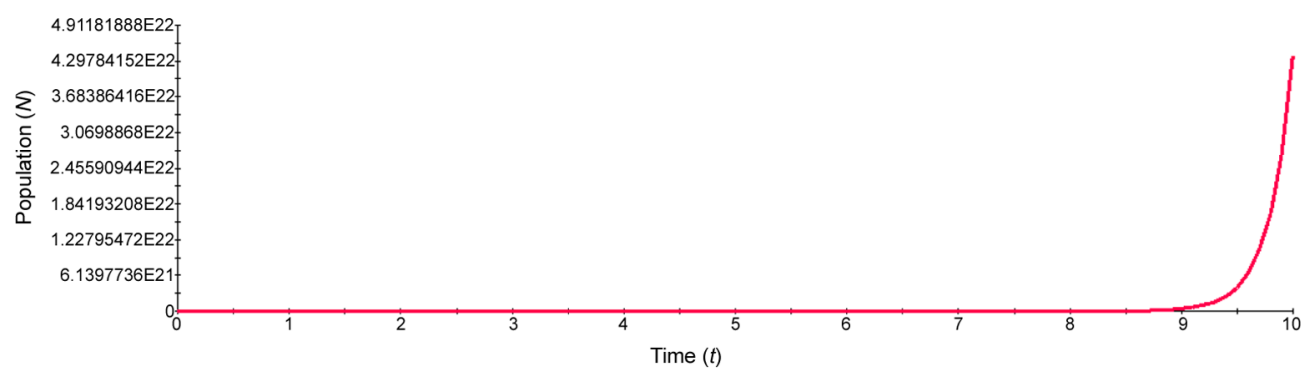

Platanthera chlorantha

Fig. 2. Forecast of the number of individuals in the populations of three species of the Orchidaceae family in NNPDS for the next 30 years based on the PVA model

Рис. 2. Прогноз чисельності особин у популяціях трьох видів родини Orchidaceae в НППдС на наступні 30 років на основі моделі PVA

ISSN 1996-4536 (print) • ISSN 2311-0783 (on-line) • Біологічні Студії / Studia Biologica • 2016 • Том 10/№2 • С. 123-132 
It must be emphasized that PVA is not a methodology of predicting the future of populations or species. It is a methodology of finding the probability of such an event, that is, the chance of survival [26].

The application of the PVA methodology in the study of the local populations of three rare plant species in NNPDS involved the premature assessment of the specific growth rate of populations. The specific growth rate $\lambda$ of the investigated populations was estimated on the basis of three-year data as the difference between the birth rate $b$ and the mortality rate $d$ of individuals in the populations. All calculations have been made with the use of the POPULUS and VORTEX computer programs. The results are shown in Fig. 2.

For $E$. helleborine the specific growth rate of the studied population $\lambda=-0.4494$ that indicates a general trend of decreasing the population size and its probable extinction in about 10-12 years.

In the $L$. ovata population $\lambda=-0.427$, and the estimated period of its probable existence also corresponds to $10-12$ years.

Due to low mortality of individuals in the $P$. chlorantha population, the specific growth rate was positive $\lambda=4.78$. In this population we can expect the sustainable conservation of the number of individuals in the next 8-9 years, and a probable active growth of this population in prospect.

Overall, taking into account the results of the consistent application of the MVP methodology, the analysis of population structure and the PVA methodology to assess the stability of the populations of three rare plant species in NNPDS, it is arguable that the local populations of $E$. helleborine and L. ovata are at a high risk, and the local population of $\mathrm{P}$. chlorantha is in a more stable condition.

The first priority for the protection of these rare plant species in NNPDS is to continue the population monitoring and record the main parameters of their condition.

\section{CONCLUSIONS}

The problem of the biodiversity reduction and loss of rare plant species is of growing relevance. Many experts are in search of the ways to objectively evaluate the stability of populations of rare plant species and the risks of their extinction in order to minimize these risks by using adequate measures for the protection of rare plants. Different methodological approaches have been used to solve the set tasks.

The analysis of the local populations of three rare plant species has been conducted to make a comparative assessment of the effectiveness of different methods of evaluation of the population stability. It has shown that the MVP method and the method of analysis of the population structure taken separately do not provide reliable information on the actual trends of the local population development, especially when the researcher has data for only 1 or 2 or 3 years. These two methods are suitable only as launching techniques at the initial stage of monitoring the status of populations of rare plant species.

Currently, the method of assessing the population viability (PVA) is more deeply developed and theory-based, and allows us to assess the population stability based on a set of properties of the individuals condition in the population and characteristics of the population as a biological unit. Progress and prospects of the PVA methodology are related to the fact that it is not just a method for the analysis of the population condition, but a powerful stimulus for long-term studies in biology and ecology of the species. Moreover, multispecies PVA is an incentive for a comprehensive study of ecosystems.

ISSN 1996-4536 (print) • ISSN 2311-0783 (on-line) • Біологічні Студії / Studia Biologica • 2016 • Том 10/№2 • С. 123-132 
The use of one of the PVA models in relation to the local populations of three species of the Orchidacea family has allowed us to assess a probable high risk of degradation of the local populations of $E$. helleborine and $L$. ovata and the relatively higher stability of the local population of $P$. chlorantha. The organization of long-term monitoring of local populations of rare plant species is recommended on all protected areas.

1. Andriyenko T.L. The rare boreal species in the plains of the Ukraine. Kyiv: Phytosociocentre, 2010. 104 p. (In Ukrainian).

2. Afanasyeva E.A. The structure of the cenopopulations of the shoe point in Olekminsky goszapovednike. Petrozavodsk: Karelian Research Centre, RAS, 2008; Ch 5: 12. (In Russia).

Didukh Y.P. The results of the third edition of the "Red Book of Ukraine - Plants”: Flora the Red Book of Ukraine: implementation of the global strategy for Plant Conservation, 2010; 12-13. (In Ukrainian).

3. Zlobin Yu.A. Ecology of plants populations: Modern status, points of growth. Sumy: University Book, 2009. 263 p. (In Ukrainian).

4. Zlobin Yu.A. The structure of knowledge in population botany: International Internet Symposium - Population Ecology of Plants, 2012; 28 p. (In Ukrainian).

Zlobin Yu.A., Sklyar V.G., Klimenko A.A. The populations of rare species of plants: theoretical foundations and methodology of the study. Sumy: University Book, 2013. $439 \mathrm{p}$ (In Ukrainian).

5. Lukash A.V. Andrienko T.L. Rare and protected plants of Polissya (Poland, Belarus, Ukraine, Russia). K.: Fitosociocentre, 2012. 168 p. (In Ukrainian).

6. Mosyakin S.L., Tykhonenko U.Y. Resolution of XVII International Botanical Congress and tasks of Ukrainian and world botany. Ukr. Bot. J, 2006; 63(1): 118-123. (In Ukrainian).

7. Plotnikov I.A. Status of the populations of species of the genus Listera (Orchidaceae) in the Crypt-llych Nature Reserve (Republic of Komi, Russia). Botany and Ecology, 2007; 167 p. (In Russian).

8. Rabotnov T.A. Life cycle of perennial herbaceous plants in the meadow cenoses. Proceedings of the Botanical Institute of the USSR. Geobotany Series, 1950; 6: 7-204. (In Russian).

9. Rakova M.V. Biology of rare species of plants reserve "Cedar Pad". Vladivostok: Dal'nauka, 1992. 175 p. (In Russian).

10. Stetsuk N.P. Status of the cenopopulations of Dactylorhiza incarnata (L.) Soo (Orchidaceae) in the Lunev Tracts area Bureya steppe Orenburg steppe reserve. Fundamental and Applied Problems of Population Biology, 2002: 166 p.

11. Red Book of Ukraine. Kyiv: Global-Consulting, 2009. 900 p.

12. Akçakaya H.R., Sjögren-Gulf P. Population viability analyses in conservation planning: an overview. Ecol. Bulletins, 2000; 48: 9-21.

13. Alstad D. The Populus help system. Minnesota: Minn. Univ, 2007. 125 p.

14. Beissinger S.R., McCullough D.R. Population viability analysis. Chicago: Univ. Chicago Press, 2002. 593 p.

15. Boyce M.S. Population viability analysis. Ann. Review Ecol. and System, 1992; 23: 481-497.

16. Brigham C.A., Schwartz M.W. Population viability in plants conservation, management and modeling of rare plants. N.Y.: Springer Verlag., 2003. 362 p.

17. Burgman M., Possingham H. Population viability analysis for conservation: the good, the bad and the undescribed. Genetics, demography and viability of fragmented population, 2000: 97-112.

18. Elderd B.D., Shahani P., Doak D.F. The problems and potential of count-based population viability analysis. Population Viability in Plants, 2003: 173-183.

19. Elzinga C.L., Salzer D.W., Gibbs J.P., Willowghly J.B. Monitoring plant and animal population. Malden: Blackwell Sci., 2001. 360 p.

ISSN 1996-4536 (print) • ISSN 2311-0783 (on-line) • Біологічні Студії / Studia Biologica • 2016 • Том 10/№2 • С. 123-132 
20. Jacquemyn H., Brys R., Hermy M., Willems J.H. Long-term dynamics and population viability in one of the last population of the endangered Spiranthes spiralis (Orchidaceae) in the Netherlands. Biol. Conserv, 2007; 134: 14-21.

21. McCarthy M.A., Possingham H.P., Day J.R., Tyre A.J. Testing the accuracy of population viability analysis. Conserv. Biol, 2001; 15(4):1030-1038.

22. Meffe G., Nielsen L.A., Knight R., Scheneborn D.A. Ecosystem management. Adaptive, community-based conservation. Washington: Island Press, 2002. 333 p.

23. Miller P.S., Lacy R.C. VORTEX: a stochastic simulation of extinction process. Apple Valley: CBSG, 2005. $150 \mathrm{p}$.

24. Morris W.F., Doak D., Groom M. et al. A practical handbook for population viability analysis. The Natur. Conserv., 1999. 83 p.

25. Noon V.R., Lamberson R.H., Boyce M.S., Irwin L.L. Population viability analysis: a primer on its principal technical concepts. Ecological Stewardship, 1999; 2: 87-134.

26. Rai U.K. Minimum sizes for viable population and conservation biology. Our Nature, 2003; 1 : 3-9.

27. Shaffer M.L. Minimum population size for species conservation. BioSci, 1981; 31(2): 131-134.

28. Tews J. Plant population viability analysis in conservation biology: a review. N.Y.: Elatis Modeling and Consulting Inc., 2004. 13 p.

\section{ОСНОВНІ ПІДХОДИ У ВИЗНАЧЕННІ СТІЙКОСТІ ПОПУЛЯцІЙ РІДКІСНИХ вИДІВ РОслИн}

Г. О. Клименко, І. М. Коваленко

Сумський національний аграрний університет вул. Г. Кондратьєва, 160, Суми 40021, Україна e-mail: hgrip@rambler.ru

Представлені результати апробації трьох методів оцінки стійкості та ймовірних трендів розвитку популяцій на прикладі рідкісних видів рослин Національного природного парку “Деснянсько-Старогутський”. Об’єктами дослідження були три види рідкісних рослин НППДС, занесених до Червоної книги України: Epipactis helleborine (L.) Crantz. (у фрітоценозі Querceto-Pinetum coryloso (avellanae)-caricosum (ericetorum), Listera ovata (L.) R. Br. (у фрітоценозі Betuleto-Pinetum coryloso (avellanae)stellariosum (holosteae) і Platanthera chlorantha (Cust.) Rchb. (спорадично трапляється по всьому Старогутському лісовому масиву). Досліджений локалітет лежить у фрітоценозі Querceto-Pinetum coryloso (avellanae)-caricosum (ericetorum). Встановлено, що метод MVP і метод аналізу структури популяцій не дають достовірної інформації про реальні тренди розвитку локальних популяцій, особливо коли в розпорядженні дослідника є дані тільки за один або за 2-3 роки. Високу ефективність має метод PVA, який дає змогу оцінювати стійкість популяцій рослин за комплексом ознак стану особин у популяції і ознак популяції як біологічної цілісності. У сукупності трьома методами з'ясовано ймовірність деградації локальних популяцій E. helleborine i L. ovata і порівняно вищу стійкість локальної популяції $P$. chlorantha. На всіх природоохоронних територіях рекомендується організація довгострокового моніторингу локальних популяцій рідкісних видів рослин.

Ключові слова: MVP методологія, PVA методологія, рідкісні рослини, популяції, стійкість, динаміка.

ISSN 1996-4536 (print) • ISSN 2311-0783 (on-line) • Біологічні Студії / Studia Biologica • 2016 • Том 10/№2 • С. 123-132 


\title{
ОСНОВНЫЕ ПОДХОДЫ К ОЦЕНКЕ УСТОЙЧИВОСТИ ПОПУЛЯЦИЙ РЕДКИХ ВИДОВ РАСТЕНИЙ
}

\author{
А. А. Клименко, И. Н. Коваленко \\ Сумский национальный аграрный университет \\ ул. Г. Кондратьева, 160, Сумы 40021, Украина \\ e-mail: hgrip@rambler.ru
}

Представлены результаты апробации трех методов оценки устойчивости и вероятных трендов развития популяций на примере редких видов растений Национального природного парка “Деснянско-Старогутский". Объектами исследования послужили три вида редких растений НППДС, занесенные в Красную Книгу Украины: Epipactis helleborine (L.) Crantz. Популяция находится в фритоценозе QuercetoPinetum coryloso (avellanae)-caricosum (ericetorum). Listera ovata (L.) R. Br. Локальная популяция размещена в фитоценозе Betuleto-Pinetum coryloso (avellanae)-stellariosum (holosteae). Platanthera chlorantha (Cust.) Rchb. Спорадически встречается по всему Старогутскому лесному массиву. Исследуемый локалитет находится в квартале 19 в фитоценозе Querceto-Pinetum coryloso (avellanae)-caricosum (ericetorum). Установлено, что метод MVP и метод анализа структуры популяций не дают достоверной информации о реальных трендах развития локальных популяций, особенно когда в распоряжении исследователя имеются данные только за один или за 2-3 года. Высокую эффрективность имеет метод PVA, позволяющий оценивать устойчивость популяций растений по комплексу признаков состояния особей в популяции и признаков популяции как биологической целостности. В совокупности три метода показали вероятность деградации локальных популяций E. helleborine и L. ovata и сравнительно более высокую устойчивость локальной популяции P. chlorantha. На всех охраняемых природных территориях рекомендуется организация долговременного мониторинга локальных популяций редких видов растений.

Ключевые слова: MVP методология, PVA методология, редкие растения, популяции, устойчивость, динамика.

Одержано: 25.04.2016

ISSN 1996-4536 (print) • ISSN 2311-0783 (on-line) • Біологічні Студії / Studia Biologica • 2016 • Том 10/№2 • С. 123-132 